\title{
Cardiac arrest caused by a pacemaker check
}

\author{
Christopher Orsborne, Gwilym Matthew Morris, Benjamin David Brown
}

Department of Cardiology, University Hospital of South Manchester, Manchester, UK

\section{Correspondence to}

Dr Christopher Orsborne, chris. orsborne@doctors.net.uk

Accepted 5 December 2014

\section{CrossMark}

To cite: Orsborne $C$, Morris GM, Brown BD. BMJ Case Rep Published online: [please include Day Month Year] doi:10.1136/bcr-2014206621

\section{DESCRIPTION}

A 75-year-old man attended a yearly pacemaker check. His VVIR device was inserted in 2008 for atrial fibrillation with a slow ventricular rate. $\mathrm{He}$ subsequently developed ischaemic cardiomyopathy, severely impaired left ventricular (LV) function and underwent tissue aortic valve replacement in 2010.

During the pacemaker check he suffered a cardiac arrest consisting of Torsades-de-Pointes and ventricular fibrillation. Cardiopulmonary resuscitation and a single DC shock restored spontaneous circulation, subsequent examination and bloods were unremarkable. Scrutiny of the pacemaker tracings revealed the cause (figure 1).

The last paced beat (VP) of the ventricular capture test at $0.5 \mathrm{~V}$ fell below the ventricular capture threshold of $0.75 \mathrm{~V}$ and did not elicit ventricular stimulation. Following this, a spontaneous ventricular escape beat (VS) fell within the refractory period $(325 \mathrm{~ms})$ of the pacemaker timing cycle. Hence the timing cycle was not reset and a paced beat at $2.5 \mathrm{~V}$ was delivered on the T-wave of the intrinsic beat (arrow). This 'R-on-T' resulted in Torsades-de-Pointes.

This is the first published case of a pacemaker check causing cardiac arrest and is unique as the pacemaker also captured the event. No fault was found with the pacemaker, it behaved as expected. In the setting of ischaemic cardiomyopathy, 35\% LV ejection fraction and an intrinsic QRSD of $160 \mathrm{~ms}$ the decision was made to upgrade to an implantable cardiac defibrillator. A cardiac resynchronisation therapy (CRT) device was not implanted on the basis that on optimal heart failure therapy he was in New York Heart Association (NYHA) class I and therefore, at the time did not fulfil eligibility criteria for CRT.

Pacemaker checks are vital to ensure safe and effective pacing in the longer term, but any device interrogation also carries a risk of rhythm disturbance. Medical staff should be trained appropriately to manage such complications.

\section{Learning points}

- Pacemaker checks are vital to ensuring safe and effective pacing in the long term.

- Device interrogation can be a useful diagnostic test when evaluating rhythm disturbance.

- An awareness of the complications of device interrogation is vital to safe practice. Cardiac arrest training and availability of a crash team is important for a service providing pacemaker checks.

Acknowledgements The authors thank Karen Elizabeth Jackson and Anne-Marie Cronin.

Contributors $\mathrm{CO}$ wrote and revised the manuscript. GMM wrote parts of, and revised, the manuscript. BDB revised the manuscript.

\section{Competing interests None.}

Patient consent Obtained.

Provenance and peer review Not commissioned; externally pee reviewed.

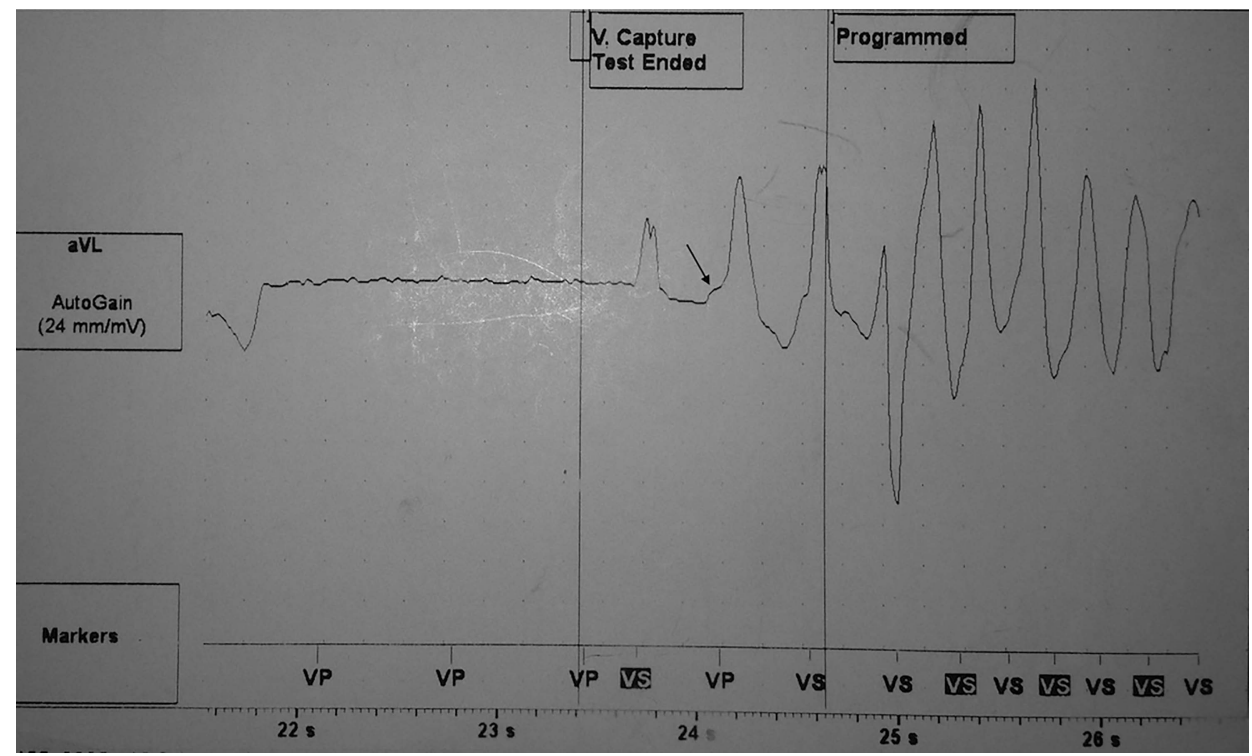

Figure 1 Ventrictular capture test. St Jude verity pacemaker with an apical St Jude tendrill lead. VP, ventricular pacing; VS, spontaneous ventricular beat. Arrow indicates where VP occurs on the peak of the T wave of the intrinsic beat (VS). 
Copyright 2015 BMJ Publishing Group. All rights reserved. For permission to reuse any of this content visit http://group.bmj.com/group/rights-licensing/permissions.

BMJ Case Report Fellows may re-use this article for personal use and teaching without any further permission.

Become a Fellow of BMJ Case Reports today and you can:

- Submit as many cases as you like

- Enjoy fast sympathetic peer review and rapid publication of accepted articles

- Access all the published articles

- Re-use any of the published material for personal use and teaching without further permission

For information on Institutional Fellowships contact consortiasales@bmjgroup.com

Visit casereports.bmj.com for more articles like this and to become a Fellow 